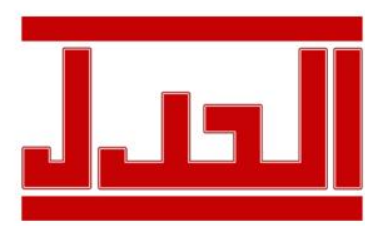

ISSN: $1979-4940$

E-ISSN: 2477-0124
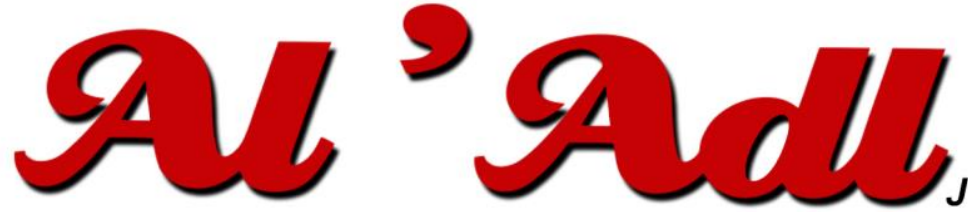

Jurnal Hukum

Editorial Office: Faculty of Law, Islamic University Of Kalimantan,

Jalan Adhyaksa No. 2 Kayutangi Banjarmasin, Kalimantan Selatan, Indonesia (70123)

Email: al_adl@uniska-bjm.ac.id

Web: http://ojs.uniska-bjm.ac.id

\section{PERLINDUNGAN HUKUM BAGI PENGGUNA LAYANAN PINJAM MEMINJAM UANG BERBASIS TEGNOLOGI INFORMASI}

\author{
Kalsum Fais \\ Magister Hukum Universitas Muhammadiyah Yogyakarta \\ Jl. Brawijaya, Geblagan, Tamantirto, Kec. Kasihan, Bantul, Daerah Istimewa Yogyakarta \\ 55183 \\ Email: kalsumfais@gmail.com
}

$\begin{array}{ll}\text { Submitted } & : \text { 15 Desember } 2020 \\ \text { Revised } & : \text { 06 Januari 2021 } \\ \text { Accepted } & : \text { 25 Januari 2021 } \\ \text { Published } & : \text { 31 Januari 2021 }\end{array}$

\begin{abstract}
The purpose of this research is to find out how the form of legal protection for users of information technologybased lending and borrowing services, the role of financial service authorities in implementing information technology-based lending and the risks faced by technology-based loan users. The research method used in this article is juridical normative, namely legal research which is carried out by examining library materials or secondary data as the basic material for research by conducting a search of the regulations and literature related to the problem under study. The results showed that information technology-based lending and borrowing services or better known as fintech lending, which offers convenience in borrowing money or credit. There was never an agreement between the operator and the loan recipient, only documents to fulfill the requirements of the operator. Legal protection for parties in online money lending and borrowing agreements can be done in a preventive and repressive manner. Preventive legal protection is carried out by applying the basic principles of the administrator before a dispute occurs. Legal protection for users of [U1] financing products, especially for lenders, to increase the confidence of modern society to improve capital requirements that are difficult to enter the market in Banking Financial Institutions. The regulations that have been issued regarding Peer to peer lending to date are the Financial Services Authority Regulation Number 77 / POJK.01 / 2016 concerning Information Technology-Based Lending and Borrowing and SEOJK Number 18 / SEJOK.01 / 2017 concerning Governance and Information Technology Risk Management in Information Technology-Based Lending and Borrowing Services have not been able to reach the interests of legal protection for users of this service.
\end{abstract}

Keywords : Legal Protection; Borrow Borrowing; Technology; Borrower;

\title{
Abstrak
}

Tujuan dari penelitian ini adalah untuk mengetahui bagaimana bentuk perlindungan hukum bagi pengguna layanan pinjam meminjam uang berbasis teknologi informasi, peran otoritas jasa keuangan dalam pelaksanaan pinjam meminjam berbasis teknologi informasi dan resiko yang dihadapi oleh pengguna pinjaman meminjam uang berbasis teknologi. Metode penelitian yang di gunakan dalam artikel ini adalah yuridis normatif, yaitu penelitian hukum yang dilakukan dengan cara meneliti bahan pustaka atau data sekunder sebagai bahan dasar 
untuk diteliti dengan cara mengadakan penelusuran terhadap peraturan-peraturan dan literatur-literatur yang berkaitan dengan permasalahan yang diteliti. Hasil penelitian bahwa layanan pinjam meminjam uang berbasis teknologi informasi atau yang lebih dikenal dengan fintech lending, dimana menawarkan kemudahan dalam meminjam uang atau kredit. Tidak pernah ada perjanjian antara penyelenggara dengan penerima pinjaman hanya ada dokumen untuk memenuhi kelengkapan syarat dari penyelenggara. Perlindungan hukum bagi para pihak dalam perjanjian pinjam meminjam uang secara online dapat dilakukan secara preventif dan represif. Perlindungan hukum secara preventif dilakukan dengan upaya menerapkan prinsip dasar dari penyelenggara sebelum terjadinya sengketa. Perlindungan hukum bagi pengguna layanan produk pembiayaan khususnya bagi pemberi pinjaman untuk meningkatkan kepercayaan masyarakat modern guna memperbaiki kebutuhan permodalan yang sulit untuk memasuki pasar dalam Lembaga Keuangan Perbankan. Peraturan yang telah dikeluarkan tentang Peer to peer lending sampai sekarang yaitu Peraturan Otoritas Jasa Keuangan Nomor

77/POJK.01/2016 tentang Pinjam Meminjam Uang Berbasis Teknologi Informasi dan SEOJK Nomor 18/SEJOK.01/2017 tentang Tata Kelola dan Manajemen Risiko Teknologi Informasi pada Layanan Pinjam Meminjam Uang Berbasis Teknologi Informasi belum dapat menjangkau kepentingan perlindungan hukum terhadap pengguna layanan ini.

Kata Kunci : Perlindungan Hukum; Pinjam Meminjam; Teknologi; Peminjam;

\section{PENDAHULUAN}

Perkembangan perekonomian Indonesia salah satunya adalah bertopang pada sektor perbankan yang ada di Indonesia. Keberadaan bank yang bertujuan untuk menunjang pelaksanaan pembangunan nasional dalam rangka meningkatkan pemerataan, pertumbuhan ekonomi, dan stabilitas nasional ke arah peningkatan taraf hidup rakyat banyak. ${ }^{1}$ Bank adalah sebagai salah satu lembaga keuangan yang fungsi utamanya sebagai penghimpun dana dan menyalurkan dana masyarakat. ${ }^{2}$ Akan tetapi, timbul permasalahan terhadap pemerataan layanan perbankan di Indonesia dalam melaksankan tugasnya untuk meningkatkan taraf hidup rakyat banyak. Hal ini terjadi karena berdasarkan letak geografis Indonesia yang merupakan negara kepulauan. Jangkauan masyarakat terhadap layanan perbankan menjadi sulit karena perbankan itu sendiri tidak merata. Layanan perbankan hanya tertumpuk di pusat kota saja, kurang menyentuh masyarakat yang ada di pelosok daerah. Hal inilah yang menyebabkan kesenjangan kesejahteraan di Indonesia akibat tidak meratanya pembangunan perekonomian nasional. Sulitnya sebagian besar masyarakat daerah untuk mendapatkan layanan perbankan menjadikannya fakta mengenai tingginya jumlah penduduk yang belum tersentuh layanan perbankan (unbanked people).

Kondisi demikian terutama terjadi di negara-negara berkembang. Di Indonesia, angka warga negara usia dewasa baik yang belum mengenal, menggunakan, atau memiliki akses pada layanan perbankan tergolong masih tinggi. Perkembangan ilmu pengetahuan dan teknologi yang semakin pesat di era digital saat ini telah mempengaruhi pola perilaku manusia

\footnotetext{
${ }^{1}$ Pasal 1 Undang-Undang Nomor 10 Tahun 1998 Perubahan Atas Undang-Undang Nomor 7 Tahun 1992 Tentang Perbankan.

${ }^{2}$ Djoni S. Gazali, Rachmadi Usman, (2016), Hukum Perbankan, Sinar Grafika, Jakarta, hlm. 4.
} 
dalam mengakses beragam informasi dan berbagai fitur layanan elektronik. Kemajuan dan perkembangan teknologi membawa perubahan secara ekonomi dan sosial. Istilah "perkembangan" membawa dampak pada "revolusi" yang menunjukan cepatnya perkembangan tersebut. Pada umumnya ini merupakan tantangan bagi hukum untuk mampu mengikuti perkembangan tersebut. ${ }^{3}$

Salah satu perkembangan teknologi yang menjadi bahan kajian terkini di Indonesia adalah Teknologi Finansial atau Financial Technology (Fintech) dalam lembaga keuangan terobosan. ${ }^{4}$ Fintech sebagai baru memberikan kemudahan akses bagi seluruh lapisan masyarakat, oleh sebab itu pada dasarnya Fintech dapat diterima dengan baik oleh masyarakat di Indonesia. Seiring dengan perkembangan masa di era globalisasi ini, apapun aktivitas masyarakat tidak akan terlepas dari bantuan teknologi. Begitu pula pada lembaga keuangan yang kini mulai bergeser pada lembaga keuangan berbasis teknologi. Salah satu kemajuan dalam bidang keuangan saat ini adanya adaptasi Fintech (Financial Technology). Fintech itu sendiri berasal dari istilah Financial Technology atau teknologi finansial. Menurut The National Digital Research Centre (NDRC), Fintech merupakan suatu inovasi pada sektor finansial. Tentunya, inovasi finansial ini mendapat sentuhan teknologi modern. Di Indonesia fintech dikenal dengan istilah Layanan Pinjam Meminjam Uang Berbasis Teknologi Informasi Pada Pasal 1 Angka 3 POJK 77/POJK.01/2016 menyebutkan bahwa Layanan Pinjam Meminjam Uang Berbasis Teknologi Informasi (fintech) adalah penyelenggaraan layanan jasa keuangan untuk mempertemukan pemberi pinjaman dengan penerima pinjaman dalam rangka melakukan perjanjian pinjam meminjam dalam mata uang rupiah secara langsung melalui sistem elektronik dengan menggunakan jaringan internet. Keberadaan Fintech dapat mendatangkan proses transaksi keuangan yang lebih praktis dan aman. ${ }^{5}$ Bentuk dasar Fintech antara lain Pembayaran (digital wallets, P2P payments), Investasi (equity crowdfunding, Peer to peer lending), Pembiayaan (crowdfunding, micro loans, credit facilities), Asuransi (risk

\footnotetext{
${ }^{3}$ Yati Nurhayati, Ifrani, A.H. Barkatullah, M. Yasir Said, (2019), "The Issue of Copyright Infringement in 4.0 Industrial Revolution: Indonesian Case”, Jurnal Media Hukum, Vol. 26, No. 2, Desember 2019, hlm. 122130.

${ }^{4}$ Imanuel Aditya Wulanata Chrismastianto, (2017), “Analisis SWOT Implementasi Teknologi Finansial Terhadap Kualitas Layanan Perbankan di Indonesia”, Jurnal Ekonomi dan Bisnis, Vol.20, Edisi 1, Fakultas Ilmu Pendidikan Universitas Pelita Harapan Tanggerang, hlm. 133.

${ }^{5}$ Fauziah Hadi, Penerapan Financial Technology (Fintech) sebagai Inovasi Pengembangan Keuangan Digital di Indonesia, terdapat dalam http://temilnas16.forsebi.org/penerapanfinancial-technology-Fintechsebagai-inovasipengembangan-keuangan-digital-di-indonesia/, Akses 5 Januari 2021, Pukul 19.00 WIB.
} 
management), Lintas - proses (big data analysis, predicitive modeling), Infrastruktur (security). ${ }^{6}$

Sedangkan Peer to Peer (P2P) Lending adalah startup yang menyediakan platform pinjaman secara online. Urusan permodalan yang sering dianggap bagian paling vital untuk membuka usaha, melahirkan ide banyak pihak untuk mendirikan startup jenis ini. Dengan demikian, bagi orang-orang yang membutuhkan dana untuk membuka atau mengembangkan usahanya, sekarang ini dapat menggunakan jasa startup yang bergerak di bidang P2P Lending. ${ }^{7}$

Sesuai dengan judul penelitian maka peneliti mengambil bentuk mengenai Peer to peer lending atau mengenai layanan pinjam meminjam uang berbasis teknologi informasi, yang dalam hal ini semakin mendapatkan perhatian publik dan regulator yakni Otoritas Jasa Keuangan (OJK) dan Bank Indonesia. Hal tersebut tertuang dalam Peraturan Otoritas Jasa Keuangan Nomor 77/POJK.01/2016 tentang Layanan Pinjam Meminjam Uang Berbasis Teknologi Informasi. Para pihak dalam layanan Fintech berbasis $P 2 P$ Lending ini terdiri dari Penyelenggara layanan pinjam meminjam berbasis teknologi informasi, Pemberi Pinjaman, dan Penerima Pinjaman. Dalam hal ini peneliti membatasi Penerima Pinjaman dalam batas Penerima Pinjaman perseorangan bukan Penerima Pinjaman badan hukum. Mekanismenya, sistem dari Penyelenggara Fintech akan mempertemukan pihak peminjam dengan pihak yang memberikan pinjaman. Jadi, boleh dikatakan bahwa dalam layanan Fintech berbasis $P 2 P$ Lending merupakan marketplace untuk kegiatan pinjam meminjam uang secara online.

Namun sangat dikhawatirkan bahwa untuk saat ini sampai dengan 6 Januari 2021 total jumlah penyelenggara Fintech terdaftar dan berizin adalah hanya sebanyak 157 perusahaan. ${ }^{8}$ Sedangkan berdasarkan data yang peneliti peroleh dari www.OJK.go.id jumlah Fintech illegal mencapai 388 yang saat ini telah dihentikan oleh ojk, belum lagi Fintech baru yang belum terdeteksi. Tentunya hal tersebut meresahkan masyarakat terutama masyarakat awam yang mudah terbuai bujuk rayu persyaratan mudah oleh Fintech illegal tersebut tanpa mengetahui resikonya.

\footnotetext{
${ }^{6}$ Nofie Iman, (2016), Financial Technology dan Lembaga Keuangan, Gathering Mitra Linkage Bank Syariah Mandiri, Yogyakarta, hlm. 6

7 https://www.duniafintech.com/pengertian-dan-jenis-startup-fintech-di-indonesia/, Akses Tanggal 5 Januari 2021, Pukul 20.05 WIB.

https://www.ojk.go.id/id/kanal/iknb/financial-technology/Pages/Penyelenggara-Fintech-LendingTerdaftar-dan-Berizin-di-OJK-per-7-Desember 2020.aspx\#: :text=\%E2\%80\%8BSampai\%20dengan\%207\%20Desember,OJK\%20adalah\%20sebanyak\%20152 \%20perusahaan.Akses 6 Januari 2021, Pukul 20.05 WIB.
} 


\section{RUMUSAN MASALAH}

Berdasarkan latar belakang masalah diatas, maka dapat dirumusakan suatu rumusan masalah yang akan diteliti yaitu sebagai berikut:

1. Bagaimana bentuk perlindungan hukum bagi pengguna layanan pinjam meminjam uang berbasis teknologi informasi ?

2. Apa saja peran otoritas jasa keuangan dalam pelaksanaan pinjam meminjam berbasis teknologi informasi?

3. Apa saja resiko yang dihadapi oleh pengguna pinjaman meminjam uang berbasis teknologi?

\section{METODE PENELITIAN}

Karya ilmiah terutama karya ilmiah penelitian hukum diharuskan menggunakan metode penelitian hukum. Ilmu hukum berusaha untuk menampilkan hukum secara integral sesuai dengan kebutuhan kajian ilmu hukum itu sendiri, sehingga metode penelitian dibutuhkan untuk memperoleh arah penelitian yang komprehensif. ${ }^{9}$ Sebenarnya ilmu hukum mempunyai ciri-ciri sebagai ilmu yang bersifat preskriptif dan terapan. Dalam preskriptif, ilmu hukum mempelajari tujuan hukum, nilai-nilai keadilan dalam suatu hukum, baik buruk suatu aturan hukum, konsep-konsep dan norma hukum. sedangkan dalam ilmu terapan, ilmu hukum menetapkan suatu prosedur, ketentuan-ketentuan dan batasan-batasan dalam menegakan suatu aturan hukum. ${ }^{10}$

Dalam penulisan jurnal ilmiah ini penulis menggunakan metode hukum yuridis normatif. Dimana dalam penelitian ini, meneliti hukum secara normatif dengan menggunakan pendekatan fakta dan pendekatan Undang-Undang. Dalam pembahasan permasalahan ini akan menggunakan aturan-aturan hukum yang ada serta bahan-bahan kepustakaan sebagai sumber dalam penulisan. Sumber hukum yang hendak diperoleh adalah melalui bahan-bahan hukum sekunder yang telah diteliti sebelumnya dan berkaitan dengan penulisan jurnal ilmiah ini. ${ }^{11}$ Kemudian pendekatan yang digunakan yaitu pendekatan berdasarkan peraturan yang ada.

Sumber data terdiri dari bahan-bahan hukum primer yaitu perundang-undangan, catatan-catatan resmi atau risalah dalam pembuatan perundang-undangan dan putusanputusan pengadilan serta bahan hukum sekunder yang digunakan dalam penulisan penelitian disertasi ini antara lain: buku-buku hukum termasuk tesis dan disertasi hukum, jurnal-jurnal

\footnotetext{
${ }^{9}$ Yati Nurhayati, "Perdebatan Metode Normatif dengan Metode Empirik Dalam Penelitian Ilmu Hukum Ditinjau Dari Karakter, Fungsi dan Tujuan Ilmu Hukum", Jurnal Al Adl, Volume 5 Npmor 10, 2013, hlm. 15.

${ }^{10}$ Yati Nurhayati, Pengantar Ilmu Hukum, Nusa Media, Bandung, 2020, hlm. 9.

${ }^{11}$ Bambang Sunggono, (2010), Metode Penelitian Hukum, Rajawali Pers, Jakarta, hlm. 86.
} 
hukum, kamus-kamus hukum dan komentar-komentar atas putusan pengadilan serta hasil penelitian sebelumnya yang terkait dengan permasalahan yang mendukung penelitian ini.

Analisis terhadap bahan hukum yaitu penulis menggali, menganalisis, dan menemukan semua peraturan perundang-undangan yang mengatur segala aspek mengenai prinsip hukum perlindungan dan pengelolaan lingkungan hidup dalam pengalihan fungsi kawasan hutan untuk usaha pertambangan sehingga dari peraturan perundang-undangan tersebut akan ditemukan beberapa spesifikasi peraturan perundangundangan yang akan sangat berguna untuk mencari prinsip hukum dalam perlindungan dan pengelolaan lingkungan hidup yang baik.

\section{PEMBAHASAN}

\section{Perlindungan Hukum Bagi Pengguna Layanan Pinjam Meminjam Uang Berbasis Teknologi Informasi}

Perlindungan hukum diartikan sebagai pemberian perlindungan kepada kepentingan individu yang dilindungi oleh hukum. Perlindungan yang ditujukan kepada konsumen dalam dunia bisnis yang dipandang baik secara materiil maupun formil semakin penting, mengingat semakin cepatnya pergerakan teknologi sebagai motor penggerak dari produktifitas produsen atas barang atau jasa yang akan dihasilkan dalam mencapai tujuan dari suatu usaha. ${ }^{12}$ Bisnis atau jasa di bidang keuangan sudah menjadi suatu bisnis yang sangat rentan terhadap berbagai tindakan-tindakan yang merugikan oleh oknum yang tidak bertanggungjawab dengan memanfaatkan keberadaan teknologi untuk melakukan suatu tindakan baik itu penyelewengan atau penyalahgunaan yang mengakibatkan kerugia bagi para pengguna layanan tersebut. ${ }^{13}$

Para penyelenggara layanan Fintech yang sudah terdaftar di Otoritas Jasa Keuangan (OJK) dalam melakukan kegiatan usahanya memiliki beberapa larangan salah satunya yaitu tidak diperbolehkan menjalankan kegiatan usaha diluar yang telah diatur dalam peraturan OJK ini, tidak diijinkan bertindak baik sebagai pemberi pinjaman ataupun sebagai penerima pinjaman tersebut, kemudian dilarang untuk memberikan informasi yang tidak sesuai dengan ketentuan yang telah berlaku, dan masih banyak larangan lainnya. Keberadaan laranganlarangan itu sendiri tujuannya adalah untuk menciptakan suatu perlindungan hukum bagi

${ }^{12}$ Desak Ayu Lila Astuti, A.A Ngurah Wirasila, (2018), Perlindungan Hukum Terhadap Konnsumen Transaksi e-commerce Dalam Hal Terjadinya Kerugian, Kertha Semaya Jurnal, Fakultas Hukum Universitas Udayana, Denpasar, hlm. 6.

${ }^{13}$ Celina Tri Siwi Kristiyanti, (2011), Hukum Perlindungan Konsumen, Sinar Grafika: Jakarta, hlm. 5 
pengguna layanan Fintech. Para penyelenggara yang ditemukan melanggar larangan yang sudah ditetapkan maka akan dikenakan sanski administratif yang berupa :
a) Peringatan tertulis,
b) denda,
c) pembatasan kegiatan dari sebuah usaha, dan
d) Pencabutan izin usaha. ${ }^{14}$

Bisnis online atau transaksi elektronik khususnya bisnis layanan jasa keuangan fintech terkait dengan adanya UndangUndang Nomor 8 tahun 1999 Tentang Perlindungan Konsumen. Masyarakat yang menjadi konsumen dalam kegiatan jual beli produk, barang atau jasa secara online atau yang melakukan pembayaran melalui internet harus lebih cermat dan selektif dan harus mendapatkan suatu bentuk perlindungan hukum untuk dapat terhindar dari berbagai ancaman kerugian yang dilakukan oleh pelaku usaha, penipuan dan kejahatan lain yang kerap terjadi dalam bisnis online terutama dalam bidang transaksi dengan media digital atau internet.

Saat ini peran dari Otoritas Jasa Keuangan (OJK) dalam memberikan perlindungan hukum terhadap konsumen sangat diperhatikan salah satunya dengan mengelurkan peraturan OJK Nomor 77/POJk.01/2016 yaitu tentang Layanan Pinjam Meminjam Uang Berbasis Teknologi Informasi yang selanjutnya disebut POJK LPMUBTI serta terdapat dalam Surat Edaran Otoritas Jasa Keuangan Nomor 2/SEOJK.07/2014 tentang Pelayanan dan Penyelesaian Pengaduan Konsumen Pada Pelaku Usaha Jasa Keuangan. Pasal 1 angka 3 POJK LPMUBTI menyatakan bahwa yang dimaksud dengan Layanan Pinjam Meminjam Berbasis teknologi Informasi merupakan penyelenggaraan layanan jasa keuangan yang bertujuan untuk mempertemukan pemberi pinjaman dengan penerima pinjaman dalam rangka melakukan perjanjian pinjam meminjam dalam mata uang rupiah secara langsung melalui sistem elektronik dengan memanfaatkan jaringan internet.

Bentuk perlindungan yang diberikan oleh OJK adalah apabila terdapat dan ditemukannya tindakan-tindakan yang melanggar dan mengakibatkan kerugian maka OJK akan meminta untuk menghentikan kegiatan usahanya tersebut. Selain itu OJK akan melakukan pembelaan hukum kepentingan masyarakat sebagai konsumen yang berupa pengajuan gugatan di pengadilan terhadap para pihak yang mengakibatkan kerugian tersebut. OJK juga akan memberikan teguran berupa peringatan terhadap para penyelenggara kegiatan 129.

\footnotetext{
${ }^{14}$ Edy Santoso, (2018), Pengaruh Era GlobalisasiTerhadap Hukum Bisnis di Indonesia, Jakarta, hlm.
} 
usaha yang dianggap menyimpang untuk dapat segera memperbaikinya, kemudian OJK memberikan informasi terkait dengan aktivitas yang dapat merugikan terhadap para konsumen ataupun masyarakat umum.

Pengawasan dan juga pengaturan bisnis dalam bidang jasa keuangan dalam pelaksanaannya harus memperhatikan peraturan-peraturan yang berkaitan dengan bidang tersebut yaitu Undang-Undang Nomor 21 tahun 2011 tentang Otoritas Jasa Keuangan, Undang Undang Nomor 11 Tahun 2008 tentang Informasi dan Transaksi Elektronik j.o Undang-Undang Nomor 19 Tahun 2016 tentang Informasi dan Transaksi Elektronik, UndangUndang Nomor 8 Tahun 1999 tentang Perlindungan Konsumen, dan peraturan-peraturan lainnya yang terkait didalamnya. Penggunaan fintech sendiri terdiri atas Kreditor dan Debitor, persayaratan-persyaratan yang diberikan harus rasional untuk diterapkan terhadap konsumen atau nasabah. ${ }^{15}$

Menurut Pasal 3 ayat (1) huruf e Peraturan Bank Indonesia Nomor 19/12/PBI/2017 Tahun 2017 tentang Penyelenggaraan Teknologi Finansial bahwa layanan pinjam uang berbasis aplikasi atau teknologi informasi merupakan salah satu jenis penyelenggaraan teknologi finansial (fintech) kategori jasa keuangan/finansial lainnya.

Menurut Pasal 5 ayat (1) Peraturan Otoritas Jasa Keuangan Nomor 77/POJK.01/2016 Tahun 2016 tentang Layanan Pinjam Meminjam Uang Berbasis Teknologi Informasi bahwa penyelenggara perjanjian pinjam meminjam uang uang berbasis teknologi informasi adalah badan hukum perseroan terbatas yang menyediakan, mengelola, dan mengoperasikan layanan pinjam meminjam uang berbasis teknologi informasi dari pihak pemberi pinjaman kepada pihak penerima pinjaman yang sumber dananya berasal dari pihak pemberi pinjaman.

Pemberi pinjaman adalah orang, badan hukum, dan/atau badan usaha yang mempunyai piutang karena perjanjian Layanan Pinjam Meminjam Uang Berbasis Teknologi Informasi. Penerima pinjaman adalah orang dan/atau badan hukum yang mempunyai utang karena perjanjian Layanan Pinjam Meminjam Uang Berbasis Teknologi Informasi. ${ }^{16}$

Pengguna layanan P2P Lending berhak mendapatkan perlindungan hukum dalam melakukan praktek layanan ini, dengan kata lain pemerintah harus menjamin kepastian hukum dalam penyelenggaraan praktek P2P Lending. Prinsip dasar dalam perlindungan seorang pengguna Layanan Pinjam Meminjam Uang Berbasis Teknologi Informasi adalah

15 Wayan Bagus Pramana , (2018), Peran Otoritas jasa Keuangan dalam Mengawasi Lembaga Keuangan Non Bank Berbasis Financial Technology Jenis Peer to Peer Lending, Jurnal Kertha Semaya, Vol. 6, No 3, hlm. 4.

${ }^{16}$ Ibid. 
bahwa penyelenggara wajib melakukan prinsip-prinsip dasar berupa transparansi, perlakuan yang adil, keandalan, kerahasiaan dan keamanan data, dan penyelesaian sengketa pengguna secara cepat, sederhana, dan biaya terjangkau. Penyelenggara wajib untuk memberikan informasi terkini yang akurat, jujur, jelas dan tidak menyesatkan. Jika ada penerimaan, penundaan, atau penolakan permohonan Layanan Pinjam Meminjam Uang Berbasis Teknologi Informasi penyelenggara wajib untuk menyampaikan informasi tersebut kepada pengguna. Perlindungan hukum menurut Philipus M. Hadjon dibagi menjadi 2 preventif dan represif, berdasarkan hal tersebut, perlindungan hukum bagi pengguna layanan pinjam meminjam uang berbasis teknologi informasi dalam praktik di Indonesia akan diuraikan sebagai berikut.

1. Perlindungan Hukum Preventif

Perlindungan hukum Preventif merupakan kesempatan kepada masyarakat untuk mengajukan suatu keberatan (inspraak) atas pendapat mereka sendiri atau secara berkelompok sebelum ada suatu keputusan pemerintah yang mendapat bentuk definitif. Sehingga, perlindungan hukum ini memiliki tujuan untuk mencegah terjadinya sengketa yang sangat besar. Dengan adanya suatu tindakan perlindungan hukum secara preventif ini, diharapkan perlindungan ini dapat mendorong agar pemerintah lebih berhati-hati dalam mengambil suatu keputusan yang terkait dengan asas freies ermessen, dan masyarakyat dapat mengajukan keberatan atau dapat juga dimintai pendapat mereka mengenai rencana keputusan tersebut. ${ }^{17}$

Perlindungan hukum preventif ini merupakan perlindungan yang memiliki sifat yaitu pencegahan, dimana sebelum seseorang itu dan/atau kelompok melakukan suatu kegiatan atau tindakan yang bersifat negatif atau melakukan suatu kejahatan yang diniatkan di dalamnya sehingga akan dapat menghindarkan atau meniadakan kejadian perbuatan yang konkrit. Sehingga diperlukan upaya integral, antara preventif dan represif agar permasalahan kejahatan dapat diatasi. ${ }^{18}$ Dalam perlindungan hukum secara Preventif pada Layanan Pinjam Meminjam Uang Berbasis Teknologi Informasi pemerintah menerbitkan beberapa peraturan terkait P2P Lending yaitu POJK LPMUBTI dan SEOJK Tata Kelola LPMUBTI.

\footnotetext{
${ }^{17}$ Philipus M. Hadjon, (2011), Pengantar Hukum Administrasi Indonesia, Yogyakarta: Gajah Mada Uneversity Press, hlm.10.

18 Ifrani \& M. Yasir Said, (2020), "Kebijakan Kriminal Non-Penal Ojk Dalam Mengatasi Kejahatan Cyber Melalui Sistem Peer To Peer Lending”, Al-Adl Jurnal Hukum, Vol.12, No.1, Januari 2020, hlm.61-76
} 
2. Perlindungan hukum represif

Perlindungan hukum represif memiliki fungsi untuk menyelesaikan apabila terjadi sengketa dikemudian hari. Agar dapat menjalankan perlindungan hukum yang represif untuk kepentingan masyarakat Indonesia, terdapat berbagai badan hukum yang secara parsial mengurus permasalahan-permasalahan yang timbul. Badan-badan tersebut selanjutnya dikelompokkan menjadi 2 (dua) bagian, yaitu:

1) Pengadilan dalam lingkup Peradilan Umum;

2) Instansi Pemerintah yang merupakan lembaga banding administrasi ${ }^{19}$

Ditinjau dari Peraturan Otoritas Jasa Keuangan Nomor 77/POJK.01/2016 tentang Layanan Pinjam Meminjam Uang Berbasis Teknologi Informasi Sanksi yang telah ditetapkan dalam POJK LPMUBTI ada dalam Pasal 47 (1) Atas pelanggaran kewajiban dan larangan dalam peraturan OJK, "OJK memiliki wewenang untuk mengenakan sanksi administratif terhadap Penyelenggara berupa:

1) Peringatan tertulis;

2) Denda, yaitu kewajiban untuk membayarkan sejumlah uang/dana tertentu;

3) Pembatasan kegiatan usaha; dan

4) Pencabutan izin."

Ditinjau dari Surat Edaran Otoritas Jasa Keuangan Nomor 18/SEOJK.02/2017 tentang Tata Kelola dan Manajemen Risiko Teknologi Informasi pada Layanan Pinjam Meminjam Uang Berbasis Teknologi Informasi SEOJK Tata Kelola LPMUBTI tidak ada aturan mengenai sanksi jika tidak memenuhi aturan yang ada didalamnya. Karena surat edaran ini diterbitkan karena berlakunya POJK LPMUBTI, maka sanksi yang dikenakan juga sesuai dengan aturan tersebut yang telah disampaikan di atas yaitu terdapat pada Pasal 47 POJK LPMUBTI.

Ditinjau dari Peraturan Otoritas Jasa Keuangan Nomor 1/POJK.07/2013 tentang Perlindungan Konsumen Sektor Jasa Keuangan Sama halnya dengan yang tertera dalam POJK LPMUBTI pula bahwa seoarang Pelaku Usaha Jasa Keuangan dan/atau pihak yang telah melanggar ketentuan dalam peraturan Otoritas Jasa Keuangan akan dikenakan sanksi administratif, antara lain berupa:

1) Peringatan tertulis;

${ }^{19}$ Zaini Zulfi Diane, (2014), Aspek Hukum dan Fungsi Lembaga Penjamin Simpanan, Keni Media, Bandung, hlm 31. 
2) Denda yaitu kewajiban untuk membayar sejumlah uang tertentu;

3) Pembatasan kegiatan usaha;

4) Pembekuan kegiatan usaha; dan

5) Pencabutan izin kegiatan usaha. ${ }^{20}$

Akan tetapi jika terjadi sengketa dikemudian hari dalam produk jenis P2P Lending masuk pada sengketa lembaga keuangan, lembaga yang berwenang dalam hal ini adalah Lembaga Alternatif Penyelesaian Sengketa (LAPS). LAPS adalah lembaga yang melakukan penyelesaian sengketa di sektor jasa keuangan. Dalam hal ini konsumen dapat mengajukan pengaduan kepada LJK untuk diselesaikan bersama secara musyawarah guna mencapai kesepakatan.

a. Mekanisme Penyelesaian Sengketa di Sektor Jasa Keuangan

Dalam interaksi antara konsumen dengan Lembaga Jasa Keuangan (LJK) yang dinamis, ditambah dengan jumlah produk dan layanan jasa keuangan yang selalu berkembang; kemungkinan terjadinya sengketa tak terhindarkan. Hal tersebut disebabkan beberapa faktor, di antaranya adalah adalah perbedaan pemahaman antara konsumen dengan LJK mengenai suatu produk atau layanan jasa keuangan terkait. Sengketa juga dapat disebabkan kelalaian konsumen atau LJK dalam melaksanakan kewajiban dalam perjanjian terkait produk atau layanan dimaksud.

Penyelesaian sengketa harus dilakukan di LJK lebih dahulu, dalam Peraturan OJK tentang Perlindungan Konsumen Sektor Jasa Keuangan diatur bahwa setiap LJK wajib memiliki unit kerja dan atau fungsi serta mekanisme pelayanan dan penyelesaian pengaduan bagi konsumen. Jika penyelesaian sengketa di LJK tidak mencapai kesepakatan, konsumen dapat melakukan penyelesaian sengketa di luar pengadilan atau melalui pengadilan. Penyelesaian sengketa di luar pengadilan dilakukan melalui Lembaga Alternatif Penyelesaian Sengketa (LAPS).

b. Layanan Penyelesaian Sengketa di LAPS

1) Mediasi Cara penyelesaian sengketa melalui pihak ketiga (mediator) untuk membantu pihak yang bersengketa mencapai kesepakatan.

${ }^{20}$ Munir Fuady, (2001), Hukum Kontrak (Dari Sudut Pandang Hukum Bisnis), Bandung,PT.Citra Aditya Bakti, hlm. 87 
2) Ajudikasi Cara penyelesaian sengketa melalui pihak ketiga (ajudikator) untuk menjatuhkan putusan atas sengketa yang timbul di antara pihak yang dimaksud. Putusan ajudikasi mengikat para pihak jika konsumen menerima. Dalam hal konsumen menolak, konsumen dapat mencari upaya penyelesaian lainnya.

3) Arbitrase Cara penyelesaian suatu sengketa perdata di luar pengadilan yang didasarkan pada perjanjian arbitrase yang dibuat secara tertulis oleh para pihak yang bersengketa. Putusan arbitrase bersifat final dan mengikat para pihak.

c. LAPS menyediakan layanan penyelesaian sengketa yang:

1) Mudah diakses;

2) Murah;

3) Cepat;

4) Dilakukan oleh SDM yang kompeten dan paham mengenai industri jasa keuangan.

d. Prinsip LAPS Berdasarkan Peraturan Otoritas Jasa Keuangan Nomor 1/POJK.07/2014 tentang Lembaga Alternatif Penyelesaian Sengketa di Sektor Jasa Keuangan, LAPS memiliki prinsip sebagai berikut:

1) Prinsip aksesibilitas Layanan penyelesaian sengketa mudah diakses oleh konsumen dan mencakup seluruh Indonesia.

2) Prinsip independensi LAPS memiliki organ pengawas untuk menjaga dan memastikan independensi SDM LAPS. Selain itu, LAPS juga memiliki sumber daya yang memadai sehingga tidak tergantung kepada Lembaga Jasa Keuangan tertentu.

3) Prinsip keadilan Mediator di LAPS bertindak sebagai fasilitator dalam rangka mempertemukan kepentingan para pihak dalam memperoleh kesepakatan penyelesaian sengketa, sedangkan ajudikator dan arbiter wajib memberikan alasan tertulis dalam tiap putusannya. Jika ada penolakan permohonan penyelesaian sengketa dari konsumen dan Lembaga Jasa Keuangan, LAPS wajib memberikan alasan tertulis. 
4) Prinsip efisiensi dan efektivitas LAPS mengenakan biaya murah kepada konsumen dalam penyelesaian sengketa. Penyelesaian sengketa di LAPS dilakukan dengan cepat. Pelaksanaan putusan diawasi oleh LAPS. ${ }^{21}$

Dasarnya regulasi tentang Perlindungan Konsumen Sektor Jasa Keuangan sebenarnya tidak mengatur atau tidak dikatan bahwa produk fintech khususnya P2P Lending ke dalam sektor perlindungan konsumen sektor jasa keuangan ini. Maka dari itu perlu adanya penyesuain regulasi dan aturan terkait perlindungan konsumen diantaranya yaitu menambahkan fintech ke dalam kerangka kerja dalam perlindungan konsumen di Indonesia khususnya sektor jasa keuangan serta juga memberikan penegasan terhadap regulasi atas hak konsumen dalam suatu hubungan usaha dengan perusahaan fintech. Dengan adanya regulasi diharapkan dapat menangani permasalahanpermasalahan utama seperti kerahasian, keamanan, integritas dan reliabilitas data yang disajikan perusahaan fintech kepada masyarakat serta perlindungan hukum terhadap pengguna-pengguna layanan fintech khususnya P2P Lending.

Dalam interaksi antara konsumen dengan Lembaga Jasa Keuangan (LJK) yang dinamis, ditambah dengan jumlah produk dan layanan jasa keuangan yang selalu berkembang; kemungkinan terjadinya sengketa tak terhindarkan. Hal tersebut disebabkan beberapa faktor, di antaranya adalah adalah perbedaan pemahaman antara konsumen dengan LJK mengenai suatu produk atau layanan jasa keuangan terkait. Sengketa juga dapat disebabkan kelalaian konsumen atau LJK dalam melaksanakan kewajiban dalam perjanjian terkait produk atau layanan dimaksud. Penyelesaian sengketa harus dilakukan di LJK lebih dahulu. Dalam Peraturan OJK tentang Perlindungan Konsumen Sektor Jasa Keuangan diatur bahwa setiap LJK wajib memiliki unit kerja dan atau fungsi serta mekanisme pelayanan dan penyelesaian pengaduan bagi konsumen. Jika penyelesaian sengketa di LJK tidak mencapai kesepakatan, konsumen dapat melakukan penyelesaian sengketa di luar pengadilan atau melalui pengadilan.

Penyelesaian sengketa di luar pengadilan dilakukan melalui Lembaga Alternatif Penyelesaian Sengketa (LAPS). Jadi dapat dikatakan bahwa jika terjadi sengketa di kemudian hari pada produk layanan fintech P2P Lending, maka lembaga penyelesaian yang berhak Sektor Lembaga Penyelesaian yang berhak dalam produk

${ }^{21}$ Muhammad Tismandico Ilham Zulfikar dan Ajrina Yuka Ardhira, (2019), "Pengawasan OJK Dalam Rangka Mitigasi Risiko Pada Peer to peer lending”, Universitas Airlangga, Vol. 24 No. 2, Mei, hlm. 90. 
keuangan P2P Lending menurut penulis adalah masuk dalam Sektor Pembiayaan dan

Pergadaian yaitu Badan Mediasi Pembiayaan dan Pergadaian Indonesia (BMPPI). ${ }^{22}$

\section{Peran Otoritas Jasa Keuangan Dalam Pelaksanaan Pinjam Meminjam Berbasis Teknologi Informasi}

Otoritas Jasa Keuangan (OJK) yang memiliki arti penting, baik itu untuk masyarakat umum dan juga bagi pemerintah, melainkan juga terhadap perkembangan dunia usaha yang ada di Indoensia. Masyarakat menganggap dengan adanya keberadaan OJK di tengah usaha atau bisnis yang sedang dijalankan akan memberikan suatu perlindungan secara hukum dan memberikan rasa aman bagi masyarakat atas investasi maupun transaksi yang sedang dilakukannya melalui lembaga jasa keuangan khususnya secara elektronik. Otoritas Jasa Keuangan (OJK) juga merupakan sebuah lembaga yang independen, bebas dari campur tangan pihak lain didalamnya. OJK Mempunyai tugas dan wewenang dalam bentuk pengaturan, pengawasan, pemeriksaan dan penyidikan sebagaimana yang telah dimaksudkan dalam Undang-Undang OJK ini sendiri. ${ }^{23}$

Keberadaan OJK saat ini sangat mendukung pesatnya pertumbuhan usaha jasa yang berbasis digital atau teknologi yang dikenal dengan sebutan "fintech"(financial technology). Hal tersebut sebagai salah satu bentuk respon yang diberikan oleh OJK terhadap perkembangan teknologi informasi dan komunikasi. Keadaan seperti ini ditambah dengan adanya star up yang semakin pesat dikalangan masyarakat sangat sulit dibendung sehingga pemerintah ikut didalamnya dengan melakukan pengawasan dan pengaturan agar keberadaan dan pelaksanaannya dapat berguna untuk masyarakat dan juga untuk pelaku bisnis di Indonesia. Bisnis fintech yang berkaitan dengan bentuk pemyaran awalnya diatur dan juga diawasi oleh BI (Bank Indonesia). Kemudian lain halnya setelah diberlakukannya UndangUndang No. 21 Tahun 2011 tentang Otoritas jasa Keuangan, tugas dan kewenangan dari Bank Indoenesia (BI) kemudian telah dialihkan kepada OJK.

Dalam pasal 5 dan pasal 6 Undang-Undang No 21 tahun 2011 yang menyebutkan bahwa fungsi dari OJK adalah melaksanakan penyelenggaraan sistem pengaturan dan pengawasan yang terintegritas kepada seluruh kegiatan dalam sektor jasa keuangan. Tugas

${ }^{22}$ Dwi Edi Wibowo, (2019), "Penerapan Konsep Utilitarianisme Untuk Mewujudkan Perlindungan Konsumen Yang Berkeadilan Kajian Peraturan Otoritas Jasa Keuangan Nomor 1/POJK.07/2013 tentang Perlindungan Konsumen Sektor Jasa Keuangan”, Fakultas Hukum Universitas Pekalongan, Vol.19 No.1, Juni, hlm. 24.

${ }^{23}$ Kasmir, (2014), Dasar-Dasar Perbankan, Raja Grafindo Persada: Jakarta, hlm. 262. 
pengaturan OJK salah satunya yaitu menetapkan peraturan pelaksanaan Undang-Undang OJK, peraturan perundang-undangan di sektor jasa keuangan, kebijakan mengenai pelaksanaan dan tugas dari OJK dan pengaturan lainnya. Kemudian dalam hal tugas pengawasan salah satunya OJK bertugas untuk menetapkan kebijakan operasional pengawasan, melakukan pengawasan, pemeriksaan, penyidikan, perlindungan konsumen dan dan atau para penyelenggara jasa keuangan. OJK sendiri melakukan tugas pengaturan dan pengawasan terhadap seluruh kegiatan di sektor perbankan, jasa keuangan di sektor pasar modal, dan kegiatan dalam sektor lembaga jasa keuangan lainnya, seperti pergadaian, lembaga penjaminan, lembaga pembiayaan ekspor di Indonesia dan jasa keuangan lainnya.

Berdasarkan ketentuan dari Undang-Undang No. 21 Tahun 2011 terlihat belum adanya pengaturan yang dapat memberikan kepastian hukum bagi masyarakat sebagai pengguna jasa keuangan Fintech tersebut, baik dalam mengatur dan juga mengawasi jasa keuangan yang berbasis teknologi (Fintech). Dalam tugasnya memberikan perlindungan terhadap konsumen ataupun masyarakat, OJK diberikan sebuah kewenangan untuk melakukan tindakan pencegahan yang berujung pada kerugian dari konsumen pengguna layanan jasa keuangan. OJK sebagai suatu lembaga yang memiliki kewenangan untuk mengatur dan mengawasi lembaga pembiayaan harus mampu berpedoman dengan cita hukum, yaitu kepastian, kemanfaatan, dan keadilan hukum agar keberadaan dari layanan jasa keuangan yang berbasis teknologi (fintech) mampu bersaing ditengah maraknya bisnis berbasis teknologi saat ini dan mampu membantu kemajuan sektor perbankan konvensional karena tidak sedikit sistem dan alat yang digunakan melibatkan pembayaran yang sudah diterbitkan oleh bank terlebih dahulu.

\section{Resiko Yang Dihadapi Oleh Pengguna Pinjaman Meminjam Uang Berbasis Teknologi}

Pinjaman online tentunya mempunyai resiko yang harus dihadapi oleh peminjam. Adapun resiko tersebut adalah:

\section{Bunga Pinjaman Online Tinggi}

Ini fakta yang harus diketahui sejak awal bahwa tingkat bunga pinjaman online relatif tinggi. Sampai saat ini, OJK tidak mengatur soal batasan bunga pinjaman online. Tingginya suku bunga diserahkan kepada market player, perusahaan pinjaman online. Perusahaan pinjaman online memiliki alasan sendiri menerapkan bunga setinggi itu. Salah satunya, tingginya resiko nasabah online, akibat kemudahan persyaratan dan kecepatan persetujuan. Selama nasabah peminjam tahu dan berhitung soal bunga yang 
harus dibayar, seharusnya tidak masalah mengambil pinjaman dengan bunga pinjaman super tinggi. Hal yang jadi masalah adalah mereka yang mengambil pinjaman online tanpa berhitung soal bunga dan baru komplain ketika sudah mengambil pinjaman yang akibatnya tidak mau atau tidak sanggup mengembalikan pinjaman.

\section{Plafond Pinjaman Kecil}

Salah satu resiko pinjaman online adalah plafond tanpa agunan yang tidak besar. Ratarata dibawah Rp 5 juta per pinjaman. Beberapa pinjaman online mulai dari 1 juta rupiah dan baru bisa meminta kenaikkan plafond setelah mengambil pinjaman beberapa kali. Sifat pinjaman online yang cepat dan mudah berimbas pada jumlah plafond yang ditawarkan. Tidak bisa mengambil untuk pinjaman dalam jumlah besar.

3. Data pribadi di aplikasi pinjaman online

Mengajukan pinjaman online, calon peminjam wajib mengunduh aplikasi pinjaman online. Nasabah mengunduh aplikasi di ponsel dan mengajukan pinjaman. Tentu saja, cara ini memberikan kemudahan yaitu kapan saja membutuhkan tinggal buka aplikasi pinjaman online di ponsel dan dapat mengajukan kredit. Namun, resikonya adalah ekspose data data pribadi di ponsel yang diminta aksesnya oleh perusahaan pinjaman online saat nasabah mengajukan pinjaman.

4. Proses persetujuan lama

Harapan yang tinggi ketika mengajukan pinjaman online adalah persetujuan cepat cair tetapi realitanya tidak semua pinjaman online bisa mewujudkan janji cepat cair tersebut. Kenyataannya, meskipun menggunakan teknologi, banyak proses di pinjaman online yang tidak bisa cepat. Butuh waktu beberapa hari sampai ada keputusan disetujui atau tidaknya.

5. Tidak bayar pinjaman online, penagih datang

Layaknya semua pinjaman, jika nasabah tidak bayar maka akan ada tindakan penagihan. Penagihan tidak akan dilakukan jika nasabah membayar tepat waktu. Ada persepsi, karena ini adalah pinjaman online, jika nasabah tidak bayar maka tidak akan ada proses penagihan dan hanya dilakukan reminder via email serta SMS, Website dan informasi di perjanjian, jelas bahwa nasabah yang tidak bayar akan ditagih oleh perusahaan pinjaman online. Sanksi apabila nasabah tidak membayar pinjaman online adalah: 
a. Perusahaan pinjaman online akan melakukan tindakan penagihan. Tindakan penagihan mulai dari yang sifatnya reminder sampai dengan intensif agar nasabah membayar kewajibannya.

b. Melaporkan nasabah ke biro kredit yang diwajibkan oleh OJK kepada setiap perusahaan Fintech. Pelaporan ini bertujuan memastikan bahwa nasabah yang tidak bayar tidak dapat mengajukan pinjaman kembali.

6. Biaya administrasi penagihan

Satu hal yang ksering dilupakan ketika menunggak, maka resikonya tidak hanya menghadapi penagihan, tetapi juga tambahan biaya karena perusahaan pinjaman online meminta biaya atas keterlambatan pembayaran (late fee). Di samping itu, karena proses penagihan membutuhkan extra sumber daya manusia, beberapa perusahaan pinjaman online membebankan biaya penagihan ke nasabah yang menunggak. Jumlah biaya penagihan ini cukup besar jika dibandingkan plafond pinjaman. Masalahnya, ketentuan soal biaya yang harus dibayar jika nasabah menunggak, tidak secara jelas dicantumkan dalam website beberapa perusahaan pinjaman online.

7. Pinjaman online belum terdaftar OJK

Perusahaan pinjaman online tidak semua terdaftar di OJK. Sejalan ketentuan, setiap lembaga yang menawarkan pinjaman online wajib mendaftar dan mendapatkan lisensi dari OJK. Salah satu cara memastikannya adalah mengecek daftar perusahaan pinjaman online yang terdaftar di OJK. ${ }^{24}$

\section{PENUTUP}

Perlindungan hukum bagi pengguna layanan produk pembiayaan khususnya bagi pemberi pinjaman untuk meningkatkan kepercayaan masyarakat modern guna memperbaiki kebutuhan permodalan yang sulit untuk memasuki pasar dalam Lembaga Keuangan Perbankan. Peraturan yang telah dikeluarkan tentang Peer to peer lending sampai sekarang yaitu Peraturan Otoritas Jasa Keuangan Nomor 77/POJK.01/2016 tentang Pinjam Meminjam Uang Berbasis Teknologi Informasi dan SEOJK Nomor 18/SEJOK.01/2017 tentang Tata Kelola dan Manajemen Risiko Teknologi Informasi pada

\footnotetext{
${ }^{24}$ Desak Ayu Lila Astuti, A.A Ngurah Wirasila, Loc. Cit.
} 
Layanan Pinjam Meminjam Uang Berbasis Teknologi Informasi belum dapat menjangkau kepentingan perlindungan hukum terhadap pengguna layanan ini.

Berdasarkan ketentuan dari Undang-Undang No. 21 Tahun 2011 terlihat belum adanya pengaturan yang dapat memberikan kepastian hukum bagi masyarakat sebagai pengguna jasa keuangan Fintech tersebut, baik dalam mengatur dan juga mengawasi jasa keuangan yang berbasis teknologi (Fintech). Dalam tugasnya memberikan perlindungan terhadap konsumen ataupun masyarakat, OJK diberikan sebuah kewenangan untuk melakukan tindakan pencegahan yang berujung pada kerugian dari konsumen pengguna layanan jasa keuangan. OJK sebagai suatu lembaga yang memiliki kewenangan untuk mengatur dan mengawasi lembaga pembiayaan harus mampu berpedoman dengan cita hukum, yaitu kepastian, kemanfaatan, dan keadilan hukum agar keberadaan dari layanan jasa keuangan yang berbasis teknologi (fintech) mampu bersaing ditengah maraknya bisnis berbasis teknologi saat ini dan mampu membantu kemajuan sektor perbankan konvensional karena tidak sedikit sistem dan alat yang digunakan melibatkan pembayaran yang sudah diterbitkan oleh bank terlebih dahulu.

Banyaknya resiko yang di hadapi oleh pengguna pinjam meminjam uang berbasis teklonogi informasi antara lain yaitu; pertama, bunga pinjaman online tinggi dalam faktanya yang harus diketahui sejak awal bahwa tingkat bunga pinjaman online relatif tinggi. Sampai saat ini, OJK tidak mengatur soal batasan bunga pinjaman online. Tingginya suku bunga diserahkan kepada market player, perusahaan pinjaman online. Kedua, Plafond pinjaman kecil yang menjadi salah satu resiko pinjaman online adalah plafond tanpa agunan yang tidak besar. Rata-rata dibawah Rp 5 juta per pinjaman, beberapa pinjaman online mulai dari 1 juta rupiah dan baru bisa meminta kenaikkan plafond setelah mengambil pinjaman beberapa kali. Ketiga, data pribadi di aplikasi pinjaman online, calon peminjam wajib mengunduh aplikasi pinjaman online. Nasabah mengunduh aplikasi di ponsel dan mengajukan pinjaman, resikonya adalah ekspose data data pribadi di ponsel yang diminta aksesnya oleh perusahaan pinjaman online saat nasabah mengajukan pinjaman. Keempat, proses persetujuan lama, harapan yang tinggi ketika mengajukan pinjaman online adalah persetujuan cepat cair tetapi realitanya tidak semua pinjaman online bisa mewujudkan janji cepat cair tersebut. Kelima tidak bayar pinjaman online penagih datang. Keenam, biaya administrasi penagihan, satu hal yang ksering dilupakan ketika menunggak, maka resikonya tidak hanya menghadapi penagihan, tetapi juga tambahan biaya karena perusahaan pinjaman online meminta biaya atas 
keterlambatan pembayaran (late fee). Ketujuh pinjaman online belum terdaftar OJK, perusahaan pinjaman online tidak semua terdaftar di OJK. Sejalan ketentuan, setiap lembaga yang menawarkan pinjaman online wajib mendaftar dan mendapatkan lisensi dari OJK.

\section{Buku}

\section{DAFTAR PUSTAKA}

Abdulkadir Muhamad, Rilda Murniati, (2000), Segi Hukum Lembaga Keuangan dan Pembiayaan. Bandung: Citra Aditya Bakti.

Asmasasmita Romli, (2014), Hukum dan Kejahatan Bisnis Teori dan Praktek di Era Globalisasi, Jakarta : Prenamedia Group.

Celina Tri Siwi Kristiyanti, (2011), Hukum Perlindungan Konsumen, Jakarta: Sinar Grafika.

David M.L. Tobing, (2013), Klausa Baku: Paradoks Dalam Penegakan Hukum Perlindungan Konsumen, Jakarta : Gramedia Pustaka Utama.

Djoni S. Gazali, Rachmadi Usman, (2016), Hukum Perbankan, Jakarta: Sinar Grafika.

Edy Santoso, (2018), Pengaruh Era Globalisasi Terhadap Hukum Bisnis di Indonesia, Jakarta.

Fuady, Munir, (2006), Hukum tentang Pembiayaan. Bandung: PT. Citra Aditya Bakti.

Hadjon, Philipus M. (2011), Pengantar Hukum Administrasi Indonesia. Yogyakarta: Gajah Mada Uneversity Press,

Kasmir, (2014), Dasar-Dasar Perbankan, Jakarta: Raja Grafindo Persada.

Kristiyanti Siwi tri Celina, (2011), Hukum Perlindungan Konsumen, Jakarta : Sinar Grafika.

M Rambli Ahmad, Gunung Pager, dan Apriadi Indra, (2007), Menuju Kepastian Hukum di Bidang Informasi dan Transaksi Elektronik, Jakarta: Departemen Komunikasi dan Informatika Republik Indonesiaa.

Maskun, (2013), Kejahatan Siber (cyber crime), Jakarta: Kencana.

Nofie Iman, (2016), Financial Technology dan Lembaga Keuangan, Yogyakarta: Gathering Mitra Linkage Bank Syariah Mandiri,.

Santoso Edy, (2018), Pengaruh Era Globalisasi Terhadap Hukum Bisnis di Indonesia, Jakarta. 
Yati Nurhayati, Pengantar Ilmu Hukum, Nusa Media, Bandung, 2020.

\section{Peraturan Perundang-Undangan}

Undang-Undang Nomor 10 Tahun 1998 Perubahan Atas Undang-Undang Nomor 7 Tahun 1992 tentang Perbankan

\section{Jurnal dan Publikasi Lainnya}

Ariati Ni Kadek, I Wayan suarbha , (2016), "Perlindungan Hukum Konsumen Dalam Melakukan Transaksi Online”, Jurnal Kertha Semaya, Vol.04, NO. 02, Februari 2016,

Astuti Lila Ayu Desak, A.A Ngurah Wirasila, (2018), "Perlindungan Hukum Terhadap Konnsumen Transaksi e-commerce Dalam Hal Terjadinya Kerugian”, Fakultas Hukum Universitas Udayana, Jurnal Kerhta Semaya Vol.06, No.2, Maret 2018,

Desak Ayu Lila Astuti, A.A Ngurah Wirasila, (2018), "Perlindungan Hukum Terhadap Konnsumen Transaksi e-commerce Dalam Hal Terjadinya Kerugian", Denpasar Kertha Semaya Jurnal, Fakultas Hukum Universitas Udayana.

Dwi Edi Wibowo, (2019), "Penerapan Konsep Utilitarianisme Untuk Perlindungan Konsumen Yang Berkeadilan Kajian Peraturan Otoritas Jasa Keuangan Nomor 1/POJK.07/2013 tentang Perlindungan Konsumen Sektor Jasa Keuangan", Jurnal Fakultas Hukum Universitas Pekalongan, Vol.19, No. 1, Juni 2019.

Ifrani \& M. Yasir Said, (2020), "Kebijakan Kriminal Non-Penal Ojk Dalam Mengatasi Kejahatan Cyber Melalui Sistem Peer To Peer Lending”, Al-Adl Jurnal Hukum, Vol.12, No.1, Januari 2020, hlm. 61-76

Imanuel Aditya Wulanata Chrismastianto, (2017), “Analisis SWOT Implementasi Teknologi Finansial Terhadap Kualitas Layanan Perbankan di Indonesia", Jurnal Ekonomi dan Bisnis, Vol.20, Edisi 1, Fakultas Ilmu Pendidikan Universitas Pelita Harapan Tanggerang,

Kornelius Benuf, (2019), "Perlindungan Hukum Terhadap Keamanan Data Konsumen Financial Technology di Indonesia", Jurnal Ilmu Hukum Fakultas Hukum Universitas Dipenogoro, Vol.3, No. 2 April 2019.

Muhammad Tismandico Ilham Zulfikar dan Ajrina Yuka Ardhira, (2019), "Pengawasan OJK Dalam Rangka Mitigasi Risiko Pada Peer to Peer Lending", Universitas Airlangga, Vol. 24, No. 2, Mei 2019.

Pramana Bagus I Wayan, (2018), "Peran Otoritas jasa Keuangan dalam Mengawasi Lembaga Keuangan Non Bank Berbasis Financial Technology Jenis Peer to Peer Lending”, Jurnal Kertha Semaya, Vol. 6, NO 3.

Ratnawaty Marginingsih, (2019), “Analisis SWOT Technology Financial (Fintech) Terhadap Industri Perbankan”, Jurnal Humaniora Fakultas Ekonomi dan Bisnis Universitas Bina Sarana Informatika, Vol.19, No. 1. Maret 2019. 
Wayan Bagus Pramana , (2018), "Peran Otoritas jasa Keuangan dalam Mengawasi Lembaga Keuangan Non Bank Berbasis Financial Technology Jenis Peer to Peer Lending”, Jurnal Kertha Semaya, Vol. 6, NO 3, hlm. 4,

Yati Nurhayati, Ifrani, A.H. Barkatullah, M. Yasir Said, 2019, "The Issue of Copyright Infringement in 4.0 Industrial Revolution: Indonesian Case", Jurnal Media Hukum, Vol. 26, No.2, Desember 2019, hlm. 122-130

Yati Nurhayati, 2013. "Perdebatan Metode Normatif dengan Metode Empirik Dalam Penelitian Ilmu Hukum Ditinjau Dari Karakter, Fungsi dan Tujuan Ilmu Hukum”, Jurnal Al Adl, Volume 5 Nomor 10.

\section{Internet}

https://www.duniafintech.com/pengertian-dan-jenis-startup-fintech-di-indonesia.

https://www.ojk.go.id/id/berita-dan-kegiatan/publikasi/Pages/PenyelenggaraFintech

Terdaftar-di-OJK-per-Desember-2018.aspx .

Fauziah Hadi, Penerapan Financial Technology (Fintech) sebagai Inovasi Pengembangan Keuangan Digital di Indonesia, terdapat dalam http://temilnas16.forsebi.org/penerapanfinancial-technology-Fintech-sebagaiinovasipengembangan-keuangan-digital-di-indonesia. 